\title{
A Decade of LMS Acceptance and Adoption Research in Sub-Sahara African Higher Education: A Systematic Review of Models, Methodologies, Milestones and Main Challenges
}

\author{
Brandford Bervell ${ }^{1 *}$, Irfan Naufal Umar ${ }^{2}$ \\ ${ }^{1}$ College of Distance Education, University of Cape Coast, Cape Coast, GHANA \\ ${ }^{2}$ Centre for Instructional Technology and Multimedia, Universiti Sains Malaysia, MALAYSIA
}

Received 3 June 2017 - Revised 18 August 2017 - Accepted 22 August 2017

\begin{abstract}
A decade has elapsed since the Learning Management System (LMS) technology permeated its way into higher education in Sub-Saharan Africa (SSA), offering new paradigms of both blended and online mode e-learning delivery. Parallel to other continents, the introduction of LMS stimulated acceptance and adoption intentions among stakeholders in higher education. This necessitated research into faculty members' and students' LMS acceptance and adoption intentions. While some research has been conducted in this dimension, the evidential facts are scattered. There is a need to agglomerate these studies to project a better picture of study patterns and results, to be abreast of the current state of the literature and better direct future research. This study sought to bridge the gap by way of a systematic review of previous studies within a decade of LMS acceptance research in SSA, placing them in contextual paradigms of models, methodologies, milestones, subjects, countries, findings and challenges. Results from a systematic review of 31 studies, revealed key determinants of LMS acceptance/adoption to be Attitude and Perceived Usefulness; followed by Performance Expectancy and Perceived Ease of Use; then lastly Social Influence. Major challenges to LMS implementation identified were ICT infrastructure; LMS usage skills and training; LMS system quality, LMS use policy and management support. TAM1 was the dominant model employed and students were the main subject of studies. Moreover, quantitative approach was the preferred design with Regression as the main statistical tool used for data analysis. The study recommended among others that more UTAUT or TAM3 based studies employing mixed method design with instructors as subjects, using structural equation modelling analysis are needed in SSA LMS research. Leadership and top management of higher education institutions should focus more on ICT infrastructure, LMS usage skills/training, LMS quality related issues, support and ICT policy formulation.
\end{abstract}

Keywords: learning management system, acceptance, adoption, e-learning, higher education, Sub-Saharan Africa

\section{INTRODUCTION}

Higher education continues to be a critical niche in terms of determining the economic gains and future development of Sub-Saharan African (SSA) countries. It has the tendency of providing both economic and social independence needed by both the individual and the public at large. Its capacity of building human capital, adapting and generating knowledge, promoting regional and international co-operation and the improvements in the global knowledge-based economies cannot be overemphasized (Yizengaw, 2008).

Nyerere, Mfune, Fuh, Sulemana, Mutisya, Yivan, Fadairo, Ameyaw and Odingo (2016), opine that higher education institutions have become the wheels on which innovation and sustainable development thrives. This has 


\section{Contribution of this paper to the literature}

- The study reviews LMS acceptance/adoption research across SSA countries and provide more complete evidence on countries in SSA that have contributed to research in this area, models employed, major acceptance intention factors and main challenges encountered in promoting LMS usage.

- Furthermore, it provides recommendations on areas for further research and methodologies that are rigorous for validating findings in LMS research in SSA.

- Finally, it makes recommendations for policy and practice in SSA technology integration in higher education, based on key findings from all the reviewed studies.

propelled governments in the countries of the sub region to widen access to its populace to enable them acquire higher education. In view of this, there has been a tremendous improvement in enrolments from 2.3 million to 5.2 million between 2000 and 2010 doubling the enrolment rate (AAI, State of Education in Africa Report, 2015). A development though positive, has had in its trail some negativity. There has now been overcrowding in lecture halls with average 50\% more students per Professor in African universities compared to the global average (AAI, 2015). This has generated a growing pressure for expansion of infrastructural facilities. A view amplified by Mohamedbhai (2011) that the increasing demand for higher education in SSA cannot be met by traditional face to face delivery alone. He recommended approaches such as open distance learning, e-learning, blended and online learning, terminologies normally used interchangeably. Accordingly, most universities in the Sub region have adopted these approaches to complement face to face mode of instruction. However, e-learning, online learning or blended learning do not operate in a vacuum, but rather underpinned by a Learning Management System (LMS) technology.

According to Sharma and Vatta (2013), "LMS is server-based or cloud-based software programme containing information about users, course and content which provides a place to learn and teach without depending on the time and space boundaries" (p.1). This definition was supported by earlier authors such as Watson and Watson (2007) and Oakes (2002). Ellis (2009) explains that these systems have the capability of providing the remedy that Sub-African institutions need to avert the challenges of soaring enrolment rates. LMS has the power to centralize and automate administration, use self-service and self-guided services; assemble and deliver learning content rapidly, consolidate training initiatives on a scalable web-based platform; support portability, standards, personalize content and enable knowledge re-use (Abdoli Sejzi \& Baharuddin, 2013). In the view of Mahdizadeh, Biemans and Mulder (2008), LMS aids organizations to better manage users, courses and instructors with testing capabilities and foster the generation of students' reports and transcripts and notifications on activities to students. This same system can accelerate the teaching and learning process as well as improve communication between users, educators, staff and students (Cavus \& Momani, 2009).

Anderson and Grolund (2009) opine that, the potential of LMS to widen access, reduce cost and improving the quality of education, will help SSA institutions to meet the growing students population (Unwin, Kleeson, Hollow, William, Oloo, Alwala \& Muianga, 2010). Based on the advantages of LMS, Farrell and Isaacs (2007) reported that, the acquisition of LMS by higher education institutions in SSA has continued to increase in recent years. Most institutions have also partnered other international organizations and spent thousands of dollars to implement various LMS solutions. Against this backdrop, Adkins (2013) predicted the growth rate of LMS acquisition in Africa sub-Sahara to increase at 5\% per annum between 2011 and 2016. Studies have confirmed that LMS have been implemented in countries such as Kenya, Tanzania, Uganda, Ghana, Nigeria, South Africa, to mention but a few (Unwin et al., 2010; Mayoka \& Kyeyume 2012; Elmahadi \& Osman 2013; Mtebe \& Raisamo 2014).

Despite the growing implementation of these e-learning solutions, authors such as Sun, Tsai, Finger, Chen and Yeh (2008) as well as Hastie, Hung, Chen and Kinshuk (2010) have all indicated that some failures exist in using LMS. A key factor observed by these authors has to do with the initial acceptance by potential stakeholders (students and instructors) who are to use it for pedagogical and other administrative purposes. According to Alkins, Coskuncay and Yildrim (2014), despite the advantages brought about by LMS based e-learning, rejection rates are also high. In the African context, this development has raised the awareness of acceptance and adoption research by several researchers considering the fact that LMS usage is still a novelty in the Sub-region. Empirical research findings have provided varying as well as complementary stance on determining antecedents of successful implementation of LMS in higher education institutions in SSA. Various research findings have revealed dimension of factors influencing behavioural intentions of LMS acceptance as well as challenges involved. However, there is a dearth of review studies that provide a holistic view of the various LMS acceptance and adoption research conducted in the SSA region. This provides a basis for the need to agglomerate these studies within the decade (2007 to 2017) to chart a definite focus specific to LMS research for guidance towards practice, and provide a current state of the literature in order to define trends for future studies. Against this background, this study seeks to fill the gap, by answering the following research questions: 
1. Which countries have contributed to LMS studies within SSA?

2. Which models have been used to study LMS acceptance and adoption in SSA?

3. What methodologies have been employed in studying LMS acceptance and adoption in SSA?

4. What are the effective factors (milestones) revealed by studies in LMS acceptance and adoption in SSA?

5. What are the main challenges confronting higher education institutions in SSA in terms of LMS implementation?

\section{METHODOLOGY}

For a systematic review of this nature, the initial step was to search databases for studies on ICT and LMS research in Africa. Popular databases such as Science Direct, Scopus, Google scholar, IEEE and an institutional database were utilized for the search. Reference sections of retrieved studies were also scanned through for related research from these databases in order to facilitate the process. Typical words used included ICT, LMS, Electronic platform, e-Learning, Blended learning, Web-based learning, Acceptance, Adoption, Higher institutions, Universities, Moodle, Sakai, Blackboard, Africa, Students and Instructors. After this, eligibility criteria based on inclusion and exclusion strategies were employed. Data obtained was then recorded in Microsoft Excel, before coded in SPSS version 20.

\section{Eligibility Criteria}

Inclusion criteria: Articles deemed relevant for the study were based on:

1. Publications in English language

2. Publications on LMS adoption or acceptance studies in Sub-Saharan Africa

3. Publications within the period of 2007-2017

4. Publications that emphasized sample size, subjects and country of study

5. Publications that focused on LMS research in higher education institutions in SSA.

Exclusion criteria: Articles were excluded based on:

1. Publications outside the Sub-Saharan region

2. Publications that merely focused on LMS implementation stages, training and technical reports

3. Publications that assessed general ICT usage perceptions

4. Publications that focused on LMS studies in second cycle institutions

5. Publications that were merely literature reviews on LMS, e-learning, blended learning and online learning in Africa.

Figure 1 depicts the process through which data was extracted from databases. 


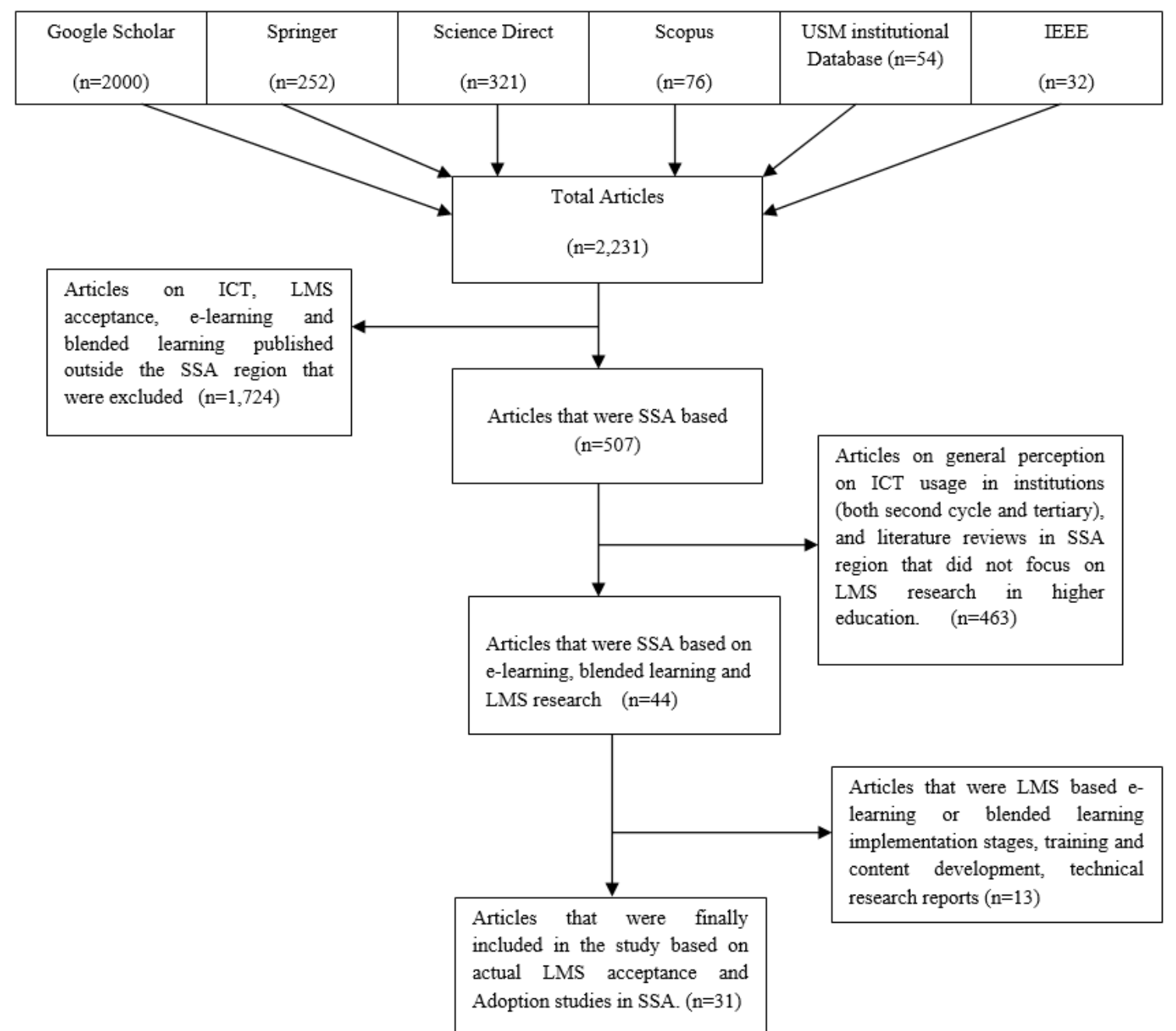

Figure 1. Hierarchical illustration of data extraction procedure

\section{Analysis}

\section{Coding technique}

1. Country: Studies were grouped according to the countries that the researches were carried out. The countries were then sub-divided into parts of Sub-Saharan Africa they belonged.

2. Study design: Three broad study designs were focused on, namely Quantitative, Qualitative and Mixed Method (Creswell, 2013).

3. Theoretical Framework: Theoretical framework based on acceptance and adoption models used in studies were also identified. Models were subdivided into Adopted (Original Model) or Adapted (Modified Model)

4. Sample size: Study sample sizes of subjects were also grouped into small, medium and large. They were coded as $(\leq 150=$ small $) ;(>150 \leq 250=$ medium $)$ and $(>250=$ Large $)$.

Subjects of study: Sample size was subdivided into subject categories of Instructors, Students or Both.

5. Statistical Instrument: Instruments employed in data analysis were grouped into Qualitative Thematic /Narrative (Creswell, 2013); Descriptive statistics; Correlation (only relationships and direction, Field, 2009); Regression /GLM's/MANOVA (Predictive and group variance, Field, 2009); and Structural Equation Modelling Technique-SEM (Kline, 2015).

6. Effective factors: Significant factors determining LMS usage intentions based on findings were identified from individual studies. 
7. Challenges: Challenges involved in LMS implementation were grouped into nine thematic areas based on findings: System Related; IT Infrastructure, Skills/Training; Technical Support; Leadership /Management Support; Policy Issues; Personal Issues; E-Content/E-Curriculum; and Time Constraints.

\section{EMPIRICAL RESULTS}

\section{Countries and Parts of Sub-Saharan Africa that Contributed to LMS Research}

Initial results revealed the countries from which studies were conducted with their corresponding number of studies. Table 1 provides this information.

Table 1. Country and Part of Sub-Saharan Africa with Number of Studies

\begin{tabular}{|c|c|c|c|c|c|}
\hline Country & $\begin{array}{l}\text { Part of } \\
\text { SSA }\end{array}$ & $\begin{array}{c}\text { Number of } \\
\text { Studies }\end{array}$ & Percentage & $\begin{array}{l}\text { No. of Studies } \\
\text { By Part of SSA }\end{array}$ & Percentage \\
\hline Ghana & Western & 6 & $19.4 \%$ & 11 & $35.5 \%$ \\
\hline Nigeria & Western & 5 & $16.1 \%$ & & \\
\hline Tanzania & Eastern & 5 & $16.1 \%$ & 10 & $32.25 \%$ \\
\hline Kenya & Eastern & 3 & $9.3 \%$ & & \\
\hline Uganda & Eastern & 2 & $6.5 \%$ & & \\
\hline Zimbabwe & Southern & 1 & $3.2 \%$ & 10 & $32.25 \%$ \\
\hline South Africa & Southern & 9 & $29.0 \%$ & & \\
\hline Total & & 31 & $100 \%$ & 31 & $100 \%$ \\
\hline
\end{tabular}

With reference to Table 1, studies spanned across seven countries in the SSA region. Out of this number, two of them were from the Western and Southern parts respectively with three countries situated in the Eastern part of SSA. With respect to number of studies, South Africa had 9, being the highest number of studies, representing $29 \%$ out the total number of 31. This was followed by Ghana with 6 studies representing $19.4 \%$. Both Nigeria and Tanzania produced 5 studies, each representing 16.1\%. Zimbabwe contributed only one study and the least, representing 3.2\%. A broader picture illustrated by Table 1, showed that the Western part of SSA had the highest frequency of studies with $11(35.5 \%)$. However, the Eastern and Southern parts produced $10(32.2 \%)$ studies each.

\section{Acceptance and Adoption Models Employed in LMS Research in Sub-Saharan Africa}

In an attempt to answer the second research question, the various models utilized in acceptance and adoption studies in SSA were collated. Table 2 depicts the results.

Table 2. Models Used in Studies

\begin{tabular}{ccccccc}
\hline Model & $\begin{array}{c}\text { Number of } \\
\text { Studies }\end{array}$ & Percentage & $\begin{array}{c}\text { Adopted } \\
\text { (Original Model) }\end{array}$ & Percentage & $\begin{array}{c}\text { Adapted (Modified } \\
\text { Model) }\end{array}$ & Percentage \\
\hline TAM & 18 & $58.1 \%$ & 9 & $29.0 \%$ & 9 & $29.0 \%$ \\
\hline UTAUT & 7 & $22.6 \%$ & 3 & $9.7 \%$ & 4 & $12.9 \%$ \\
\hline ISS & 2 & $6.5 \%$ & 1 & $3.2 \%$ & 1 & $3.2 \%$ \\
\hline IDT & 1 & $3.2 \%$ & - & - & 1 & $-2 \%$ \\
\hline None & 3 & $9.7 \%$ & - & - & 15 & - \\
\hline Total & 31 & $100 \%$ & 13 & & & \\
\hline
\end{tabular}

Highlights from Table 2 indicate that most studies (18) representing 58.1\% employed the TAM as the theoretical model suitable for their research. Half of these studies (9) modified the model while the remaining half adopted the original model. The second model of preference was the UTAUT, being utilized in 7 studies representing $22.6 \%$. In 3 of the studies that used this model, the authors adopted the original model while 4 of them modified it. Three out of the 31 studies representing $9.7 \%$ did not use any model for their studies. IDT had the least utilization being adapted in only one study making up $3.2 \%$ of the total. Overall, out of the 28 studies that made use of a model, 13 of them adopted the original models while the remaining 15 adapted or modified them.

\section{Methodologies Employed in LMS studies in Sub-Saharan Africa}

With respect to research question three, the methodologies employed were subdivided into Research Design, Data Collection Instruments, Subjects, Sample Size and Statistical Tools used for analysis. 


\section{Design and Instruments}

The first aspects of the methodology assessed were the research design and instruments adopted for the various studies. Emphasis on these is provided in Table 3.

Table 3. Research Design and Instruments

\begin{tabular}{cccccc}
\hline \multirow{2}{*}{ Design } & \multirow{2}{*}{ No. of Stds. } & \multirow{2}{*}{ Percentage } & \multicolumn{2}{c}{ Instruments } \\
\cline { 5 - 6 } & & & Questionnaire & Interview & Both Questionnaire \& Interview \\
\hline Quantitative & 25 & $80.60 \%$ & $25(80.6 \%)$ & & \\
\hline Qualitative & 2 & $6.50 \%$ & & $2(6.50 \%)$ & $4(12.9 \%)$ \\
\hline Mixed Method & 4 & $12.9 \%$ & & & \\
\hline Total & 31 & $100 \%$ & & & \\
\hline
\end{tabular}

Important details from Table 3 demonstrate that, the quantitative research design dominated most of the studies. This is underpinned by the fact that 25 out of the total studies representing $80.60 \%$ employed this research design. This was followed by the mixed method approach recording $4(12.9 \%)$ studies with qualitative design being the least used. In terms of the instruments utilized for data collection, the questionnaire was the most used instrument by 25 studies representing $80.6 \%$ followed by a mix of both questionnaire and interview, 4 (12.9\%), with interview only (2), being the least instrument used for collecting data.

\section{Subjects and Sample Size}

The subjects selected for studies and their corresponding sample sizes are depicted in Table 4.

Table 4. Subjects and Sample Size

\begin{tabular}{cccccc}
\hline \multirow{2}{*}{ Design } & \multirow{2}{*}{ No. of Stds. } & \multirow{2}{*}{ Percentage } & \multicolumn{3}{c}{ Sample Size } \\
\cline { 5 - 6 } & & & $<=\mathbf{1 5 0}$ Small & $\mathbf{1 1 5 0 <} \mathbf{2 5 0}$ Medium & $\boldsymbol{2 5 0}$ Large \\
\hline Instructors & 6 & $19.4 \%$ & $4(12.9 \%)$ & - & $2(6.5 \%)$ \\
\hline Students & 18 & $58.1 \%$ & $2(6.5 \%)$ & $5(16.1 \%)$ & $11(35.5 \%)$ \\
\hline Both Instructors \&Students & 7 & $22.6 \%$ & $2(6.5 \%)$ & - & $5(16.1 \%)$ \\
\hline Total & 31 & $100 \%$ & $8(25.9 \%)$ & $5(16.1 \%)$ & $18(58.1 \%)$ \\
\hline
\end{tabular}

Details from Table 4 indicate that out of the 31 studies reviewed, 18 of them representing $58.1 \%$ used university students as their subject of study. For the remaining studies, 7 (22.6\%) of them made use of both instructors and students as subjects. Only 6 (19.4\%) out of the 31 studies focused on instructors alone for their research. With respect to sample sizes, the range was between small for 8 studies, medium size for 5 studies and large size for 18 studies representing $58.1 \%$. In sum, 18 out of the 31 studies used large sample sizes for their research.

\section{Statistical Instruments/Tools Employed for Analysis}

A key aspect of the quality and reliability of research findings rests on the statistical instrument or tool utilized for analysis. In view of this, the study sought to find out the various statistical tools employed for analysis in LMS research in SSA. This is shown in Table 5.

Table 5. Statistical Tools

\begin{tabular}{ccc}
\hline Statistical Tool & No. of Studies & Percentage \\
\hline Thematic/Narrative & 2 & $6.5 \%$ \\
\hline Descriptive & 4 & $12.9 \%$ \\
\hline Correlation & 4 & $12.9 \%$ \\
\hline Regression/Chi-square/GLM's/MANOVA & 16 & $51.6 \%$ \\
\hline Structural Equation Modelling (SEM) & 5 & $16.1 \%$ \\
\hline Total & 31 & $100 \%$ \\
\hline
\end{tabular}

From Table 5, majority of the studies (n: 16 or 51.6\%) used predictive and group difference analysis tools in their data analysis. This was followed by SEM analysis recording 5 studies with the lowest being thematic and narrative data analysis, mainly for qualitative data. Descriptive and correlation statistical tools shared 4 studies each, representing $12.9 \%$ apiece. 


\section{Effective Factors Determining LMS Usage Intention in SSA}

In an effort to answering research question four of this study, the researchers catalogued the various factors reported across the reviewed studies as determinants of LMS usage intentions. Results from the review of those studies yielded 33 factors with their frequencies of occurrence. Figure 2 depicts the results.

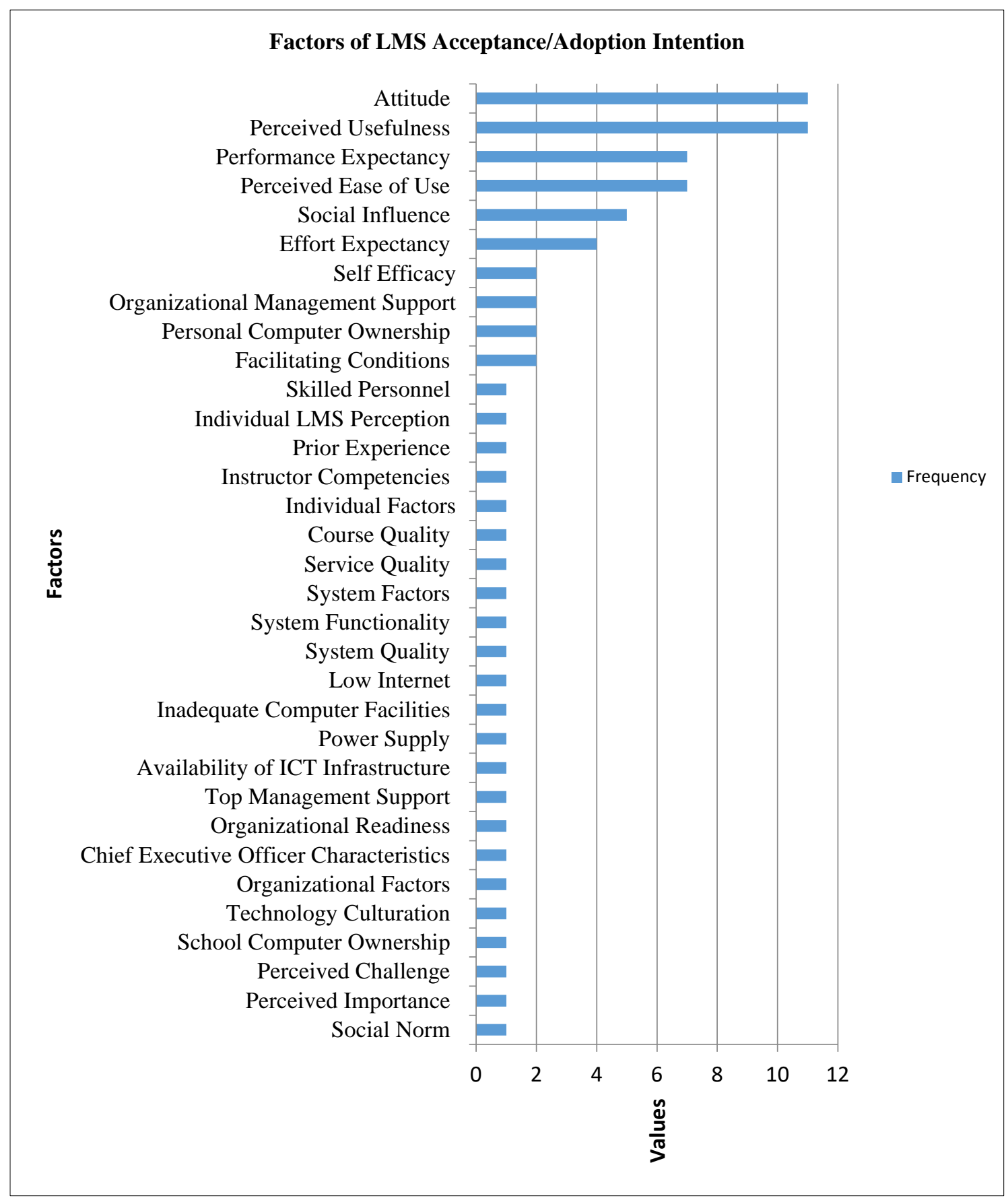

Figure 2. Effective Factors of LMS Usage Intention

With reference to the statistics in Figure 2, there is the indication of higher frequencies of 11 each for Perceived Usefulness and Attitude, followed by Perceived Ease of Use and Performance Expectancy that shared frequency of 7 each. Social influence was the next important factor with 5 occurrences. 


\section{Main Challenges Involved in LMS Implementation in SSA}

In analysing challenges outlined in those studies, only 18 out of the total of 31 studies reviewed, reported LMS implementation challenges. A total number of 60 challenges were identified from these 18 studies. These were then grouped into nine thematic areas. This is illustrated in Figure 3.

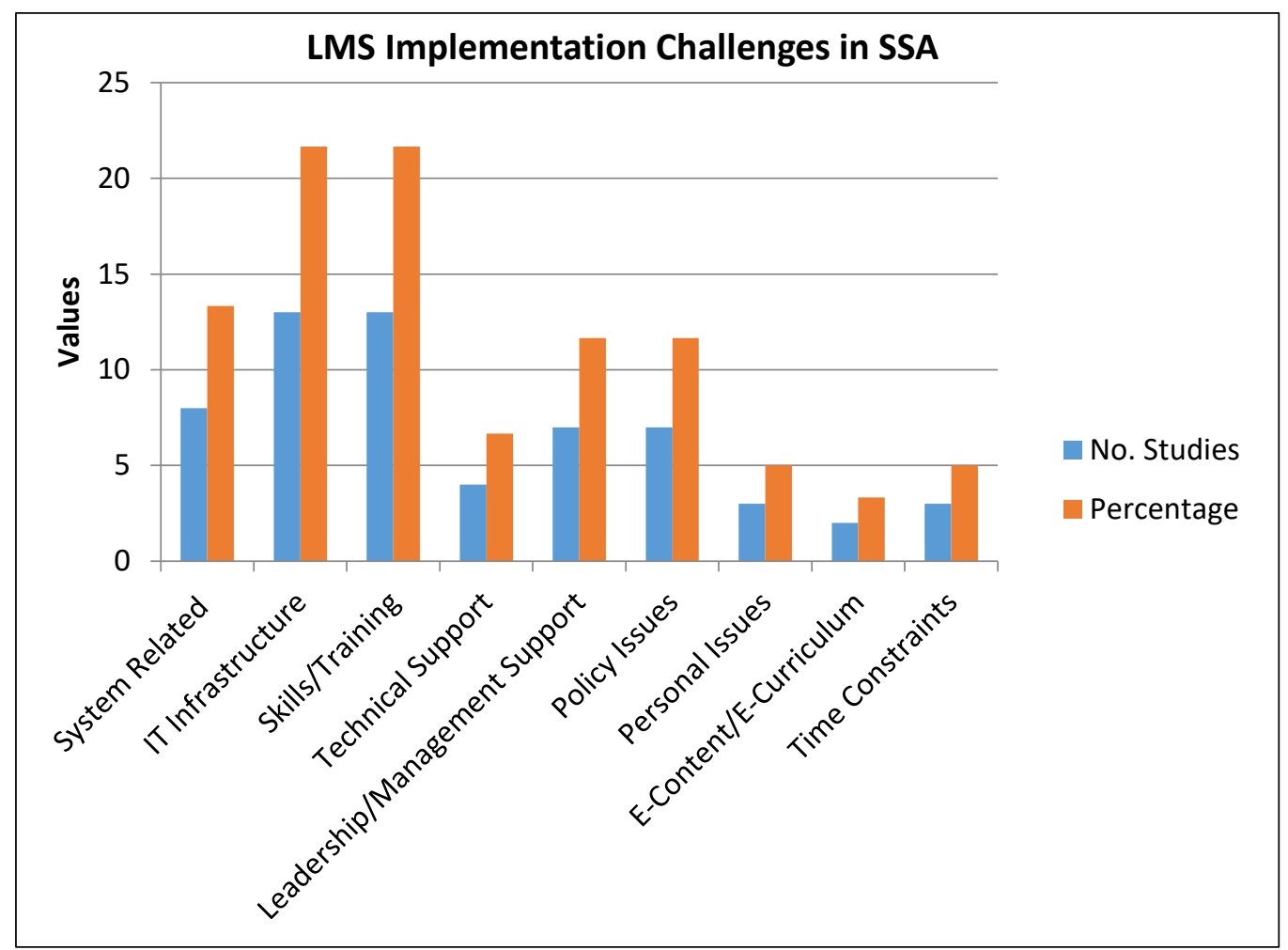

Figure 3. LMS Implementation Challenges in SSA

With reference to Figure 3, challenges were categorized into system related; IT infrastructure; skills/training; technical support; leadership and management support; policy issues; personal issues; e-content and e-curriculum; and finally, time constraints. Out of these nine challenging areas, most of the studies reported major challenges to be IT infrastructure and skills/training. These two crops of challenges were indicated by 13 studies each, out of the total of 18 studies that revealed challenges in LMS implementation. They were represented by $21.7 \%$ each. The next challenge deemed crucial in the studies was system related issues. Eight studies reported on this, representing $13.3 \%$. Two groups of challenges, leadership and management support as well as policy issues obtained 7 frequencies each representing $11.7 \%$. The least identified challenge was e-content and e-curriculum. This category had only two indicators with $3.3 \%$.

\section{DISCUSSION, CONCLUSION AND RECOMMENDATIONS}

\section{Summary and Discussion of Findings}

The results of the study revealed that South Africa had the highest number of LMS acceptance studies followed by Ghana and Nigeria. This is not so surprising since according to World Bank (2016) report on country classification by income, South Africa was classified as an upper middle income country, with Ghana, Nigeria and Kenya as lower middle income countries, then Tanzania and Uganda as low income countries respectively. As an upper middle income country, South Africa has committed resources to the educational sector in the integration of ICT in higher education since 2005. N'gambi, Brown, Bozalek, Gachago and Wood (2016) cite Czerniewicz, Ravjee and Mlitwa, (2006), that South African Higher education institutions have concentrated on obtaining LMS and CMS coupled with putting in place ICT infrastructure since 2005. This caused an ascendancy of e-learning schemes in these higher educational institutions which necessitated more LMS acceptance studies. Within the Ghanaian context, Asunka (2008) indicated that, there was a trend of higher education institutions acquiring LMS platforms especially Moodle and Sakai. Aguele (2007) from Nigeria, also revealed that, according to the report of the Partnership for Higher Education in Africa (2007), ICT solutions have been implemented in higher educational 
institutions in Tanzania, Uganda, South Africa, Nigeria and Ghana. This in part justifies why the above-mentioned countries researched in LMS studies. However, the results in terms of number of studies in LMS from SSA are considered far too low against the background that 48 countries make up the Sub-Saharan African region (Raschen, 2016). The growing acquisition and implementation of LMS in higher education institutions as indicated by Unwin et al., (2010), have not paralleled with that of research studies in LMS. With cross-cultural differences and diverse geographical settings, coupled with unique characteristics and economic disparities, a pool of research studies on LMS from the majority of these countries will enable authors; carve a better view based on comparative research results on LMS in terms of intention prone factors and challenges faced within the region. As indicated by Venkatesh and Zhang (2010), differences in national culture play important roles in technology research findings.

In the matter of models employed in LMS studies in SSA, the Technology Acceptance Model (TAM) was the most dominant framework used by researchers. UTAUT was the next, in terms of frequency of usage in the LMS related reviewed studies. Thus, over a decade of existence, UTAUT is still not popular in research in the SSA terrain. Park (2009) reiterated that more than a few researchers have used TAM to provide explanation on how individuals adopt and use e-learning or online learning systems. This was earlier supported by Venkatesh (2000) that TAM was the most widely applied model of users' technology acceptance research. However, this review found out that most of the studies in SSA that utilized TAM were basically based on TAM1 developed by Davis, Baggozzi and Warshaw (1989). TAM1 positions perceive usefulness and attitude as determinants of user intentions and perceive ease of use as independent variable for both attitude and perceive usefulness. This takes away the direct effects of perceive ease of use on intention towards usage. TAM1 also limits the external effects of social norm and external control variables such as environmental factors or facilitating conditions (Bagozzi, 2007). A criticism shared by Chuttur (2009) that these limitations render TAM as trivial, limited in practical value and explanatory power.

This limitation creates a vacuum in terms of unravelling the various factors that determine intention behaviours. In a reaction to the simplicity of TAM, Bagozzi (2007) commented that, “...in favoring a simple model, researchers have overlooked essential determinants of decisions and action..." (p.2). A more practical aspect of the model will be TAM2 or TAM3 which provide some extensions. Alternatively, UTAUT could be of more value since it has all four variables (performance expectancy, effort expectancy, social influence and facilitating conditions (in recent studies) determining BI and has been proven to outperform all other technology acceptance models (Venkatesh, Morris, Davis \& Davis, 2003). With moderators within the UTAUT model, contextual factors distinct to regions of studies could be added to test for incidence of differences in intentions. As indicated by Venkatesh et al., (2003) cultural differences play a key role in technology use intention decisions. Although authors such as Kaba and Touré (2014) opine that the UTUAT model does not really perform in African research, exclusive to LMS studies, much more research with UTAUT is needed in SSA to ascertain this assertion.

With respect to research design and instruments used in LMS research in SSA, majority of the reviewed studies applied the quantitative approach. A limitation of using only the quantitative approach is to ignore narrative details that could be helpful in augmenting the findings obtained by way of quantitative analysis (Creswell, 2013). Though quantitative approach is rigorous, a more effective approach will be the addition of a qualitative component. According to Creswell (2013), mixed method procedures employ aspects of both quantitative methods and qualitative procedures and have increased in popularity in recent years. A blend of quantitative and qualitative mixed method research has the potential to benefit most research projects (Johnson, Onwuegbuzie \& Turner, 2007). In information systems research, Venkatesh, Brown and Bala (2013) argue that there is the need to bridge the quantitative and qualitative gap. The strengths of mixed methods research design offer a better way to explain and understand the complexities involved in organizational and social phenomena, especially in terms of technology acceptance (Venkatesh et al., 2013). Thus, it behoves on information system researchers in SSA to utilize mixed methods to conduct research. This will aid in employing both structured and open-ended questionnaire or with interview guide in the data collection exercise to complement for weaknesses likely to occur when only one type of instrument is used.

Findings from the review pointed out the fact that most of the studies (18 out 31) used students as subjects of study. Research that focused on instructors alone were only 6 . The importance of instructors' technology adoption belief has come up in current literature. For instance, Salleh (2016) suggests that instructors' belief about technology needs to be understood to support the complex interrelationships with students and the general educational setting. This stance was earlier supported by Beswick (2006) who stated that it will be very beneficial for research to be a more greatly and explicitly focused on instructors' belief. This is against the backdrop that instructors tend to extend their influences which in turn shape students' belief system. This is particularly important when addressing issues of educational reform (Cooney, Shealy \& Aryold, 1998) such as utilization of LMS for instruction. Furthermore, some authors have criticised the use of students as subjects particularly in LMS acceptance research. Lee, Kozar and Larsen (2003) provided a criticism on students used as subjects in LMS technology acceptance research, when they indicated that students are mostly interested in grades and other motivating factors and thus cannot provide results generalized to the real world. Lecturers on the other hand unperturbed by grades, fear or 
favour, are likely to come out genuinely with negative factors hampering on LMS usage. Generally, when instructors hold a positive view about technology integration, they are likely to positively influence students to use it and vice versa. It thus becomes necessary to focus on instructors' usage intentions as they are direct implementers of technology in the teaching and learning process and can serve as immediate guides and role models to students.

Dominant statistical analysis tools adopted for data analysis by studies in LMS acceptance in SSA was the Regression/Chi-square/GLM's/MANOVA category. Regression and Chi-square (for categorical variables) analyses produce results on the predictive strength of independent variables on a dependent variable (Field, 2009). However, GLMS's (ANOVA, ANCOVA; and the MANOVA as the non-parametric form of multivariate analysis), test for significance of variances and co-variances between and within groups (Field, 2009). Usage of these statistical tools was very positive as they extended the analysis beyond mere relationship testing. However, almost all studies with the exception of Evans and Le Roux (2015), failed to provide results on effect sizes ( $\left.\mathrm{f}^{2}\right)$ of factors that predicted usage intentions and predictive relevance $\left(\mathrm{Q}^{2}\right)$ of models adopted or adapted. Statistically, it is not adequate to just have information about the factors that predict behavioural intention to towards LMS acceptance, effect sizes and model predictive relevance provide a better understanding of the value of predictive factors as well as the relevance of models employed. According to Hair, Hult, Ringle and Sarstedt (2017), beyond the examination of significant relationships of factors in a model, there is the pertinence to evaluate the relevance of these significant relationships. Hair et al., (2017) express a concern that, many studies ignore this essential stage in their analyses but merely centre on the statistical significance of factor effects. The authors argue that though "the path coefficients in the model may be significant, their size may be so small that they do not warrant managerial attention" (p.g.173). Thus analyses of effect sizes of predictive factors are crucial for interpreting the results and drawing conclusions (Hair et al., 2017). As an evaluative extension to magnitude of the $\mathrm{R}^{2}$ values as a criterion of model predictive accuracy, Hair et al., (2017) strongly recommend researchers to examine Stone-Geisser's Q2 value (Geisser, 1974; Stone, 1974 cited in Hair et al., 2017). This analysis offers a more accurate measure and aptly indicates the general predictive relevance of models. Such comprehensive analysis is produced by utilizing the Structural Equation Modelling (SEM) approach which provides a more robust and detailed results for both measurement and structural models. Conversely, the results of this review revealed that only 5 studies used this approach. There is therefore a dearth of LMS studies in SSA employing SEM for data analysis.

Major determinants of LMS usage intentions unravelled by the study were Attitude and Perceived Usefulness; Performance Expectancy; Perceived Ease of Use; and Social Influence, according to their order of priority and importance. Attitude as a personality factor has appeared in many studies as having a significant association with successful LMS use intentions (El-Gayar, Moran \& Hawkes, 2011). A positive attitude towards LMS use has a strong effect on acceptance and vice-versa. Attitude of instructors and students are influenced by certain factors such as training, availability of ICT facilities, awareness of e-learning solutions etc. (Meerza \& Beauchamp, 2017). In TAM, key determinants of attitude are theorized as Perceived Ease of Use and Perceived Usefulness (Davis, Bagozzi \& Warshaw, 1989). Easiness of use of LMS as perceived by instructors and students relate positively with their attitude. When instructors and students perceive that LMS usage will be easy for them, they will tend to attach usefulness to it which fosters an eagerness to use the system. Their perceptions of usefulness generate in them a realization that usage of LMS will be accompanied by benefits towards teaching and learning. Benefits to be accrued from usage urge them to develop a positive attitude towards LMS usage. The relationship between Perceive Usefulness and Perceive Ease of Use in TAM is similar to that of Performance Expectancy and Effort Expectancy in UTAUT. According to Venkatesh et al. (2003), when potential adopters of an information system believe that usage is likely to benefit them by way of promotion, raise in salary or increase in output gains, it affects positively their intention behaviour. Performance however depends to a greater extent on how an individual will be able to use the system. When novel adopters expect that effort required to use a system is minimal, they attach importance to the system and in turn influences positively their acceptance intentions. Instructors' and students' behavioural intentions to use LMS are also a function of certain environmental and social intervention factors. Aside the effectiveness of and easiness to use an information system, end users may only utilize the system after they have been motivated by important others, which later influence their attitude and behaviour (Taiwo \& Downe, 2012). The implication is that, instructors and students also rely to a larger extent on the encouragement by these social acquaintances and relevant referent others to make up their final intentions to use LMS for pedagogical and andragogical purposes.

The success or otherwise of LMS implementation have been to overcome identified challenges. For higher institutions in SSA, the reviewed studies highlighted five major challenges: ICT infrastructure; skills/training; system related usability issues; leadership/management support; and LMS usage policy. Top on this list were ICT infrastructure and skill/training needs. This was followed by system related issues. The third level challenges of importance were leadership/management support and LMS usage policy. Lack of ICT infrastructural development in the deployment of LMS in SSA has been in the literature as a major barrier. Anene, Imam and Odumuh (2014) indicated that lack of ICT infrastructure in terms of internet, computers and other hardware facilities coupled with lack of computer literacy skills and training, are critical barriers affecting acceptability of e-learning solutions. This 
view was supported by Daniel (2009) who revealed that barriers impinging on implementation of e-learning solutions in developing countries have been internet connectivity, computer hardware and software equipments; and training (Aboderin, 2015). Žuvi_-Butorac and Nebi (2009) on the other hand, highlighted the need for institutions to be the back-bone for LMS implementation. They stressed that LMS enabled e-learning implementation supported by institutions with aided capacity building by way of training, is often the right choice. System accessibility (ability to log in, download content, chat online etc.) affects satisfaction with LMS which in turn has effect on continuous usage. According to Shin and Kang (2015), easy accessibility to LMS has a positive influence on perceive ease of use. Users' perception of the easiness in LMS usage determines how useful the system is to them, which later convinces them on their intention to accept LMS; a view earlier shared by Park, Nam and Cha (2012). On the other hand, institutional policies are also pertinent to LMS implementation success and a number of studies have revealed this (for instance: Czerniewicz \& Brown, 2009, Boezerooij, van der Wende, \& Huisman, 2007). Czerniewicz and Brown (2009) emphasized that policy comprises goals, values and resources that institutions are eager to commit to LMS implementation. This demands an examination of existing systems, services and structures to ensure LMS usage implementation. According to Nicholas (2008), the formulation of these policy statements spells out commitment by top management or leadership on tactical ownership required at the peak (Czerniewicz \& Brown, 2009), for uptake of e-learning solutions in SSA institutions.

\section{Conclusion}

The paper reviewed studies on LMS acceptance and adoption with the intention of establishing the dominant models employed by researchers for LMS acceptance in SSA. It further unravelled the methodologies used for these studies by way of the design, subjects, sample size, instruments used and statistical analysis tools. Finally, it looked into the milestone findings and the challenges institutions of higher education in SSA face in implementing LMS solutions. This further established the current state of the literature and determined the direction of future studies, policy and practice.

\section{Recommendations for Future Research}

1. The study recommends that future studies should focus more on using mixed method design to unravel acceptance and adoption factors in LMS research in SSA.

2. Future studies should employ more of UTAUT for acceptance studies to highlight the effects of social influence, effort expectancy and facilitating conditions on usage intentions of LMS in SSA and test for moderators that are of contextual value.

3. Studies that employ TAM should use a more advanced version like TAM2 or TAM3 to be able to bring out direct effects of other factors such as subjective norm, perceive ease of use and perceive usefulness with other moderators such as experience and voluntariness on usage intentions.

4. Future studies should employ more complex statistical analysis procedures such as the Structural Equation Modelling technique to ascertain predictive relevance of models, effect sizes of usage intention factors as well as assessing their performance and importance to highlight key factors.

5. Studies should also report on challenges or barriers to LMS implementation in SSA and provide measures to mitigate such obstacles.

6. Future studies should focus more on unravelling usage or adoption intention of LMS by instructors in higher education institutions.

7. Much more research is needed in LMS acceptance and adoption in SSA as only 7 countries out of the 48 SubSaharan countries have provided some studies in this dimension.

\section{Recommendations for Policy and Practice}

1. Leadership and management of higher education institutions should have a re-prioritization of funds allocation towards a more intentional ICT infrastructural development and periodic skills training in LMS usage, coupled with a definite policy framework, if LMS adoption is to have sustenance in SSA.

2. Leadership and management of higher education institutions in SSA should make the frantic efforts to sensitize instructors and students on the benefits, usefulness and importance of using LMS in instructional delivery. In addition, support systems should be put in place to make LMS usage much easier. These aforementioned initiatives have the likelihood to generate positive attitude in instructors and students which in turn promotes acceptance and adoption of LMS solutions. 


\section{Limitations}

1. The study concentrated only on LMS acceptance intentions in higher education in Sub-Saharan Africa neglecting focus on K-12 and second cycle institutions.

2. The study also singled out only LMS as a technology of focus without considering other technologies.

\section{ACKNOWLEDGEMENTS}

The authors acknowledge all authors who contributed in LMS acceptance/adoption research in SSA higher educational institutions. We also appreciate the PhD sponsorship by College of Distance Education, University of Cape Coast, which formed a part of this research work.

\section{REFERENCES}

Abdoli Sejzi, A., \& Baharuddin A. (2013). Learning Management System (LMS) and Learning Content Management System (LCMS) at Virtual University. 2nd International Seminar on Quality and Affordable Education (ISQAE 2013).

Aboderin, O. S. (2015). The challenges and prospects of e-learning in National Open University of Nigeria. Journal of Education and Learning (EduLearn), 9(3), 207-216.

Adkins, S. S. (2013). Ambient Insight Regional Report: The Africa Market for Self-paced eLearning Products and Services: 2011-2016 Forecast and Analysis, 2011-2016. http://www.ambientinsight.com/Resources/Documents/AmbientInsight-2011-2016-AfricaSelfPacedeLearning-Market-Abstract.pdf

Africa American Institute. (2015). A report card on the progress, opportunities and challenges confronting the African education sector. State of Education in Africa Report 2015.

Aguele, L. I. (2007). Information and communication technology in universities in Nigeria: Challenges for teaching and learning. Retrieved on July, 20, 2011.

Alkis, N., Coskunçay, D. F., \& Yildirim, S. Ö. (2014, September). A systematic review of Technology Acceptance Model in e-learning context. In Proceedings of the XV International Conference on Human Computer Interaction, 55. ACM.

Anene, J., Imam, H., \& Odumuh, T. (2014). Problem and prospect of e-learning in Nigerian universities. International Journal of Technology and Inclusive Education (IJTIE), 3(2), 320-327.

Bagozzi, R. P. (2007). The legacy of the technology acceptance model and a proposal for a paradigm shift. Journal of the association for information systems, 8(4), 3 .

Beswick, K. (2006). The importance of Mathematics teachers' belief. Australian Mathematics Teacher, 62(4), 17-22.

Boezerooij, P., van der Wende, M., \& Huisman, J. (2007). The need for e-learning strategies: Higher education institutions and their responses to a changing environment. Tertiary Education and Management, 13(4), 313330.

Cavus, N., \& Momani, A. M. (2009). Computer aided evaluation of learning management systems. Procedia Social and Behavioral Sciences, 1, 426-430.

Cooney, T. J., Shealy, B. E., \& Arnvold, B (1998). Conceptualizing belief structures of preservice secondary mathematics teachers. Journal for Research in Mathematics Education, 29(3), 306-333.

Chuttur, M. Y. (2009). Overview of the Technology Acceptance Model: Origins, Developments and Future Directions. Indiana University, USA, Sprouts: Working Papers on Information Systems.

Creswell, J. W. (2013). Research design: Qualitative, quantitative, and mixed methods approaches. Sage publications.

Czerniewicz, L., \& Brown, C. (2009). A study of the relationship between institutional policy, organisational culture and e-learning use in four South African universities. Computers E Education, 53, 121-131.

Czerniewicz, L., \& Brown, C. (2006). The virtual Mobius strip. Retrieved on June 15, 2017 from https:// telearn.archives-ouvertes.fr/hal-00190318

Daniel, J. (2009). E-earning for Development: Using Information and Communications Technologies to Bridge the Digital Divide. Common Wealth Ministers Reference. London: Henley Media Group.

Davis, F. D., Bagozzi, R. P., \& Warshaw, P. R. (1989). User acceptance of computer technology: A comparison of two theoretical models. Management science, 35(8), 982-1003.

El-Gayar, O., Moran, M., \& Hawkes, M. (2011). Students' Acceptance of tablet PCs and implications for educational institutions. Educational Technology \& Society, 14(2), 58-70. 
Ellis, R. K. (2009). Field Guide to Learning Management Systems, ASTD Learning Circuits. Retrieved 7th June, 2017 from http://www.astd.org/ /media/Files/Publications/LMS_fieldguide_20091.pdf

Evans, N. D., \& Le Roux, J. (2015). Modelling the acceptance and use of electronic learning at the University of Zululand. South African Journal of Libraries and Information Science, 81(2), 26-38.

Farrell, G., \& Isaacs, S. (2007). Survey of ICT and Education in Africa: A Summary Report, Based on 53 Country Surveys, 0-74. Washington, DC. United States. Retrieved June 16, 2017 from http://www.Infodev.org/en/Publication.353.html

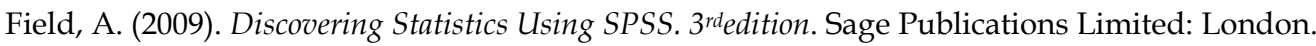

Geisser, S. (1974). A predictive approach to the random effects model. Biometrika, 61, 101-107.

Hastie, M., Hung, I-C., Chen, N.S. \& Kinshuk (2010). A blended synchronous learning model for educational international collaboration. Innovations in Education and Teaching International, 47(1), 9-24.

Hair, J. F., Hult, G. T. M., Ringle, C. M., \& Sarstedt, M. (2017). A Primer on Partial Least Squares Structural Equation Modeling. $2^{\text {nd }}$ edition. Thousand Oaks: Sage.

Johnson, R., Burke, O., Anthony J., \& Turner, L. A. (2007). Toward a definition of mixed method research. Journal of Mixed Methods Research, 1(2), 112-133.

Kline, R. B. (2015). Principles and Practice of Structural Equation Modelling Methodology in the Social Sciences, $4^{\text {th }}$ edition. Guilford Publication: NY.

Lee, Y., Kozar, K. A., \& Larsen, K. R. (2003). The technology acceptance model: Past, present, and future. Communications of the Association for information systems, 12(1), 50.

Mahdizadeh, H., Biemans, H., \& Mulder, M. (2008). Determining factors of the use of e-learning environments by university teachers. Computers in Education, 51, 142-154.

Mayoka, K., \& Kyeyune, R. (2012). An analysis of e-learning information system adoption in Ugandan universities: Case of Makerere University Business School. Information Technology Research Journal, 2, 1, 1-7.

Meerza, A., \& Beauchamp, G. (2017). Factors influencing attitudes towards information and communication technology (ICT) amongst undergraduates: An empirical study conducted in Kuwait Higher Education Institutions (KHEIS). The Turkish Online Journal of Educational Technology, 16(2).

Mohamedbhai, G. (2011). Higher Education in Africa: Facing the challenges in the 21st century. International Higher Education, 63, 20-21.

Mtebe, J., S., \& Raisamo, R. (2014). A model for assessing Learning Management System Success in Higher Education in Sub-Saharan Countries. The Electronic Journal of Information Systems in Developing Countries, EJISDC, 61(7), 1-17.

Ng'ambi, D., Brown, C., Bozalek, V., Gachago, D., \& Wood, D. (2016). Technology enhanced teaching and learning in South African higher education - A rear view of a 20 year journey. British Journal of Educational Technology, 47(5), 843-858.

Nichols, M. (2008). Institutional perspectives: The challenges of e-learning diffusion. British Journal of Educational Technology, 39(4), 598-609.

Nyerere, J., Mfune, O., Fuh, D., Sulemana, N., Mutisya, E., Yiran, G., Fadairo, O., Ameyaw, J., \& Odingo, A. (2016). The role of higher education in building a sustainable African society. AJSD, Special Edition, 4(3).

Oakes, K. (2002). E-learning: LCMS, LMS- They're not just acronyms but powerful systems for learning. Training $\mathcal{E}$ Development, 56(3), 73-75.

Park, S. Y., Nam, M. W., \& Cha, S. B. (2012). University students' behavioral intention to use mobile learning: Evaluating the technology acceptance model. British Journal of Educational Technology, 43(4), 592-605.

Park, S. Y. (2009). An analysis of the technology acceptance model in understanding university students' behavioral intention to use e-learning. Educational Technology \& Society, 12(3), 150-162.

Raschen, M. (2016). With good politics, sub-Saharan Africa can make up more lost ground. Focus on Economics, 135, (9).

Salleh, S. (2016). Examining the influence of teachers' beliefs towards technology integration in classroom. The International Journal of Information and Learning Technology, 33(1), 17-35.

Sharma, A., \& Vatta, S. (2013). Role of Learning Management Systems in education. International Journal of Advanced Research in Computer Science and Software Engineering, 3(6).

Shin, W. S., \& Kang, M. (2015). The use of a mobile learning management system at an online university and its effect on learning satisfaction and achievement. The International Review of Research in Open and Distributed Learning, 16(3). 
Stone, M. (1974). Cross-validatory choice and assessment of statistical predictions. Journal of the Royal Statistical Society, 36, 111-14 7.

Sun, P., C., Tsai, R. J., Finger, G., Chen, Y. Y., \& Yeh, D. (2008). What drives a successful e-learning? An empirical investigation of the critical factors influencing learner satisfaction. Computers and Education, 50(4), 1183-1202.

Taiwo, A. A., Downe, A. G., \& Mahmood, A. K. (2012). User acceptance of E-government: Integrating risk and trust dimensions with UTAUT model. In proceedings at the International Conference on Computer and Information sciences. Kuala Lumpur.

The partnership for Higher Education in Africa. (2007b). ICT and internet in membership countries. Retrieved May 23, 2017 from http://www.foundationpartnership.org/pubs/bandwidth/index.php?chap=chap2\&sub

UNESCO. (2010). Trends in Tertiary Education: Sub-Saharan Africa. UIS Fact Sheet, December 2010, No. 10.

Unwin, T., Kleessen, B., Hollow, D., Williams, J., Oloo, L. M., Alwala, J., Mutimucuio, I., Eduardo, F., \& Muianga, X. (2010). Digital Learning Management Systems in Africa: Myths and realities. Open Learning: The Journal of Open and Distance Learning, 25(1), 5-23.

Venkatesh, V., \& Zhang, X. (2010). Unified Theory of Acceptance and Use of Technology: US vs. China. Journal of Global Information Technology Management, 13(1), 5-27.

Venkatesh, V. 2000. Determinants of perceived ease of use: Integrating control, intrinsic motivation, and emotion into the technology acceptance model. Information Systems Research, 11(4), 342-365.

Venkatesh, V., Morris, M. G., Davis, G. B., \& Davis, F. D. (2003). User acceptance of information technology: Toward a unified view. MIS Quarterly, 27(3), 425-478.

Venkatesh, V., Brown, S. A., \& Bala, H. (2013). Bridging the qualitative-quantitative divide: Guidelines for conducting mixed methods research in information systems. MIS quarterly, 37(1), 21-54.

Watson, W. R., \& Watson S. L. (2007). An argument for clarity: what are learning management systems, what are they not, and what should they become? TechTrends, Springer Verlag, 51(2), 28-34.

Yizengaw, T. (2008). Challenges of Higher Education in Africa and lessons of experience for the Africa - U.S. Higher Education Collaboration Initiative. A Synthesis Report Based On Consultations Made Between March-April, 2008 And Review Of Literature Related To Higher Education And Development In Africa Washington D.C., Working Paper.

Žuvi-Butorac, M., \& Nebi, Z. (2009). Institutional support for e-learning implementation in higher education practice: A case report of University of Rijeka, Croatia. Proceedings of the ITI 2009 31st Int. Conference on Information Technology Interfaces, June 22-25, 2009, Cavtat, Croatia. 
APPENDIX A

Summary of Reviewed Studies

\begin{tabular}{|c|c|c|c|c|c|}
\hline $\begin{array}{l}\text { Authors/ } \\
\text { Reference }\end{array}$ & $\begin{array}{l}\text { Title/ } \\
\text { Purpose }\end{array}$ & Country \& Model & $\begin{array}{l}\text { Design \& } \\
\text { Instruments }\end{array}$ & $\begin{array}{l}\text { Sample \& } \\
\text { Subjects }\end{array}$ & $\begin{array}{l}\text { Statistical } \\
\text { Tools }\end{array}$ \\
\hline $\begin{array}{l}\text { Essel \& Wilson } \\
(2017)\end{array}$ & $\begin{array}{l}\text { Factors Affecting University Students' Use of Moodle: } \\
\text { An Empirical Study Based on TAM }\end{array}$ & $\begin{array}{l}\text { Ghana } \\
\text { TAM }\end{array}$ & $\begin{array}{l}\text { Quantitative: } \\
\text { Questionnaire }\end{array}$ & $\begin{array}{l}229 \\
\text { students }\end{array}$ & $\begin{array}{l}\text { Multiple } \\
\text { Regression } \\
\end{array}$ \\
\hline $\begin{array}{l}\text { Asampana, } \\
\text { Akanferi \& Ami- } \\
\text { Narh (2017) }\end{array}$ & $\begin{array}{l}\text { Reasons For Poor Acceptance Of Web-Based } \\
\text { Learning Using An LMS and VLE In Ghana }\end{array}$ & $\begin{array}{l}\text { Ghana } \\
\text { TAM+ OPC+IP }\end{array}$ & $\begin{array}{l}\text { Quantitative: } \\
\text { Questionnaire }\end{array}$ & $\begin{array}{l}870 \\
\text { Students }\end{array}$ & $\begin{array}{l}\text { GLM } \\
\text { (Regression } \\
\text { Based) } \\
\end{array}$ \\
\hline $\begin{array}{l}\text { Nicholas- } \\
\text { Omoregbe, Azeta, } \\
\text { Chiazor } \\
\text { \&Omoregbe } \\
(2017)\end{array}$ & $\begin{array}{l}\text { Predicting the Adoption of E Learning Management } \\
\text { System: A Case of Selected Private Universities in } \\
\text { Nigeria }\end{array}$ & $\begin{array}{l}\text { Nigeria UTAUT +ATT } \\
+ \text { Technology Culturation+ } \\
\text { Power }\end{array}$ & $\begin{array}{l}\text { Quantitative: } \\
\text { Questionnaire }\end{array}$ & $\begin{array}{l}472 \\
\text { Students }\end{array}$ & PLS-SEM \\
\hline Dlalisa (2017) & $\begin{array}{l}\text { Acceptance and Usage of Learning Management } \\
\text { System Amongst Academics }\end{array}$ & $\begin{array}{l}\text { South Africa } \\
\text { TAM }\end{array}$ & $\begin{array}{l}\text { Mixed } \\
\text { Method: } \\
\text { Questionnaire } \\
+ \text { Interviews } \\
\end{array}$ & $\begin{array}{l}111 \\
\text { Instructors }\end{array}$ & $\begin{array}{l}\text { Correlation }+ \\
\text { Thematic/ } \\
\text { Narrative } \\
\text { Analysis }\end{array}$ \\
\hline $\begin{array}{l}\text { Tibyampansha, } \\
\text { Ibrahim, Kapanda, } \\
\text { Tarimo,Minja, } \\
\text { Kulanga, } \\
\text { Muiruri,Mteta, } \\
\text { Kessy, Bartlett } \\
\text { (2017) }\end{array}$ & $\begin{array}{l}\text { Implementation of a Learning Management System } \\
\text { for Medical Students: A Case Study of Kilimanjaro } \\
\text { Christian Medical University College }\end{array}$ & Tanzania & $\begin{array}{l}\text { Mixed } \\
\text { Method: } \\
\text { Questionnaire } \\
+ \text { Interviews }\end{array}$ & $\begin{array}{l}1356 \\
\text { students \& } \\
69 \text { lecturers }\end{array}$ & $\begin{array}{l}\text { Multiple } \\
\text { Regression + } \\
\text { Thematic/ } \\
\text { Narrative } \\
\text { Analysis }\end{array}$ \\
\hline $\begin{array}{l}\text { Muries \& Masele } \\
(2017)\end{array}$ & $\begin{array}{l}\text { Explaining Electronic Learning Management Systems } \\
\text { (ELMS) continued usage intentions among facilitators } \\
\text { in Higher Education Institutions (HEls) in Tanzania }\end{array}$ & $\begin{array}{l}\text { Tanzania TAM + } \\
\text { Organizational- } \\
\text { Management Support } \\
\end{array}$ & $\begin{array}{l}\text { Quantitative: } \\
\text { Questionnaire }\end{array}$ & $\begin{array}{l}264 \\
\text { students }\end{array}$ & Regression \\
\hline $\begin{array}{l}\text { Boateng, Mbrokoh, } \\
\text { Boateng, } \\
\text { Senyo \& Ansong } \\
\text { (2016) }\end{array}$ & Determinants of e-learning adoption among students & $\begin{array}{l}\text { Ghana } \\
+ \text { CSE }\end{array}$ & $\begin{array}{l}\text { Quantitative: } \\
\text { Questionnaire }\end{array}$ & $\begin{array}{l}337 \\
\text { students }\end{array}$ & SEM \\
\hline $\begin{array}{l}\text { Okantey \& Addo } \\
(2016)\end{array}$ & $\begin{array}{l}\text { Effect of Theoretical and Institutional Factors on The } \\
\text { Adoption of E- Learning }\end{array}$ & $\begin{array}{l}\text { Ghana TAM } \\
+ \text { Institutional Factors }\end{array}$ & $\begin{array}{l}\text { Quantitative: } \\
\text { Questionnaire }\end{array}$ & $\begin{array}{l}600 \\
\text { Lecturers }\end{array}$ & $\begin{array}{l}\text { Correlation } \\
\text { and } \\
\text { Regression }\end{array}$ \\
\hline $\begin{array}{l}\text { Mafuna \& } \\
\text { Wadesango (2016) }\end{array}$ & $\begin{array}{l}\text { Exploring Lecturers' Acceptance Level of Learning } \\
\text { Management System (LMS) at Applying the Extended } \\
\text { Technology Acceptance Model (TAM) }\end{array}$ & South Africa IDT+ Attitude & $\begin{array}{l}\text { Quantitative: } \\
\text { Questionnaire }\end{array}$ & 30 lecturers & $\begin{array}{l}\text { Descriptive } \\
\text { Statistics } \\
\text { (Percentages) }\end{array}$ \\
\hline $\begin{array}{l}\text { Mkhize, Mtsweni } \\
\text { \&Buthelezi (2016) }\end{array}$ & $\begin{array}{l}\text { Diffusion of Innovations Approach to the Evaluation } \\
\text { of Learning Management System Usage in an Open } \\
\text { Distance Learning Institution }\end{array}$ & South Africa IDT+ Attitude & $\begin{array}{l}\text { Quantitative: } \\
\text { Questionnaire }\end{array}$ & $\begin{array}{l}156 \\
\text { Students }\end{array}$ & $\begin{array}{l}\text { Correlation } \\
\text { and } \\
\text { Regression }\end{array}$ \\
\hline $\begin{array}{l}\text { Mbabazi \& Ali } \\
(2016)\end{array}$ & $\begin{array}{l}\text { Evaluation of E-Learning Management Systems by } \\
\text { Lecturers and Students in } \\
\text { Ugandan Universities: A Case of Muni University }\end{array}$ & $\begin{array}{l}\text { Uganda } \\
\text { Model }\end{array}$ & $\begin{array}{l}\text { Quantitative: } \\
\text { Questionnaire }\end{array}$ & $\begin{array}{l}130 \\
\text { students \& } \\
10 \text { lecturers }\end{array}$ & $\begin{array}{l}\text { Descriptive } \\
\text { Statistics } \\
\text { (Mean) }\end{array}$ \\
\hline $\begin{array}{l}\text { Kabarungi } \\
\text { Musiimenta \& } \\
\text { Atuhe (2016) } \\
\end{array}$ & $\begin{array}{l}\text { Impact of E- Learning Management System } \\
\text { Adoption at Mbarara University of Science and } \\
\text { Technology }\end{array}$ & Uganda & $\begin{array}{l}\text { Qualitative: } \\
\text { Interview }\end{array}$ & $\begin{array}{l}10 \text { students } \\
\& \\
10 \text { lecturers }\end{array}$ & $\begin{array}{l}\text { Thematic/ } \\
\text { Narrative } \\
\text { Analysis }\end{array}$ \\
\hline $\begin{array}{l}\text { Maina \& Nzuki } \\
(2015)\end{array}$ & $\begin{array}{l}\text { Adoption Determinants of E-learning Management } \\
\text { System in Institutions of Higher Learning in Kenya: A } \\
\text { Case of Selected Universities in Nairobi Metropolitan }\end{array}$ & UTAUT & $\begin{array}{l}\text { Mixed } \\
\text { Method: } \\
\text { Questionnaire } \\
+ \text { Interviews }\end{array}$ & $\begin{array}{l}600 \\
\text { lecturers, } \\
\text { students \& } \\
\text { administrat } \\
\text { ors }\end{array}$ & $\begin{array}{l}\text { Correlation + } \\
\text { Thematic/ } \\
\text { Narrative } \\
\text { Analysis }\end{array}$ \\
\hline $\begin{array}{l}\text { Olatubosun, } \\
\text { Olusoga, \& Samuel } \\
(2015)\end{array}$ & $\begin{array}{l}\text { Adoption of eLearning Technology in Nigerian } \\
\text { Tertiary Institution of Learning }\end{array}$ & $\begin{array}{l}\text { Nigeria UTAUT+ } \\
\text { SE+ANX+ Willingness } \\
+ \text { Online skill }\end{array}$ & $\begin{array}{l}\text { Quantitative: } \\
\text { Questionnaire }\end{array}$ & $\begin{array}{l}627 \\
\text { students }\end{array}$ & Lisrel SEM \\
\hline $\begin{array}{l}\text { Chinyamurindi \& } \\
\text { Shava } \\
(2015) \\
\end{array}$ & $\begin{array}{l}\text { An investigation into e-learning acceptance and } \\
\text { gender amongst final year students }\end{array}$ & $\begin{array}{l}\text { South Africa TAM+CSE+ } \\
\text { Gender }\end{array}$ & $\begin{array}{l}\text { Quantitative: } \\
\text { Questionnaire }\end{array}$ & $\begin{array}{l}113 \\
\text { students }\end{array}$ & MANOVA \\
\hline $\begin{array}{l}\text { Chipps, Kerr, } \\
\text { Brysiewicz \& } \\
\text { Walters (2015) }\end{array}$ & $\begin{array}{l}\text { A Survey of University } \\
\text { Students' Perceptions of Learning Management } \\
\text { Systems in a Low-Resource Setting Using a } \\
\text { Technology Acceptance Model }\end{array}$ & $\begin{array}{l}\text { South Africa TAM+ Org. } \\
\text { Factors+ System Factors } \\
\text { +Ind. Factors }\end{array}$ & $\begin{array}{l}\text { Quantitative: } \\
\text { Questionnaire }\end{array}$ & $\begin{array}{l}274 \\
\text { Students }\end{array}$ & $\begin{array}{l}x^{2} \text { difference } \\
\text { Test } \& \\
\text { Regression }\end{array}$ \\
\hline $\begin{array}{l}\text { Evans \& Le Roux } \\
(2015)\end{array}$ & $\begin{array}{l}\text { Modelling the acceptance and use of electronic } \\
\text { learning at the University of Zululand. }\end{array}$ & $\begin{array}{l}\text { South Africa } \\
\text { UTAUT }\end{array}$ & $\begin{array}{l}\text { Quantitative: } \\
\text { Questionnaire }\end{array}$ & $\begin{array}{l}405 \\
\text { Students \& } \\
73 \\
\text { Instructors }\end{array}$ & PLS-SEM \\
\hline
\end{tabular}




\begin{tabular}{|c|c|c|c|c|c|}
\hline $\begin{array}{l}\text { Lwoga \& Komba } \\
\text { (2015) }\end{array}$ & $\begin{array}{l}\text { Antecedents of continued usage intentions of web- } \\
\text { based learning management system in Tanzania }\end{array}$ & $\begin{array}{l}\text { Tanzania } \\
\text { Modified UTAUT + Self } \\
\text { efficacy }\end{array}$ & $\begin{array}{l}\text { Mixed } \\
\text { Method: } \\
\text { Questionnaire } \\
\text { + Interviews }\end{array}$ & $\begin{array}{l}300 \\
\text { students \& } \\
20 \text { Lecturers }\end{array}$ & $\begin{array}{l}\text { Multiple } \\
\text { Regression + } \\
\text { Thematic/ } \\
\text { Narrative } \\
\text { Analysis } \\
\end{array}$ \\
\hline $\begin{array}{l}\text { Adjin-Tettey } \\
(2014)\end{array}$ & $\begin{array}{l}\text { Adoption and Utilisation of Learning /Course } \\
\text { Management Systems: The Study Of University of } \\
\text { Professional Studies, Accra }\end{array}$ & $\begin{array}{l}\text { Ghana } \\
\text { TAM }\end{array}$ & $\begin{array}{l}\text { Quantitative: } \\
\text { Questionnaire }\end{array}$ & $\begin{array}{l}655 \\
\text { Students }\end{array}$ & Correlation \\
\hline $\begin{array}{l}\text { Namisiko, Munialo } \\
\text { \& Nyongesa (2014) }\end{array}$ & $\begin{array}{l}\text { Towards an Optimization Framework for E Learning in } \\
\text { Developing Countries: A Case of Private Universities in } \\
\text { Kenya }\end{array}$ & $\begin{array}{l}\text { Kenya } \quad \text { TAM+ } \\
\text { Technology Organization } \\
\text { Environment (TOE) }\end{array}$ & $\begin{array}{l}\text { Quantitative: } \\
\text { Questionnaire }\end{array}$ & $\begin{array}{l}224 \\
\text { Students, } \\
31 \\
\text { Lecturers \& } \\
17 \\
\text { Administrat } \\
\text { ors }\end{array}$ & Regression \\
\hline $\begin{array}{l}\text { Olatubosun, } \\
\text { Olusoga \& Shemi } \\
(2014)\end{array}$ & $\begin{array}{l}\text { Direct Determinants of User Acceptance and Usage } \\
\text { behavior of eLearning System in Nigerian Tertiary } \\
\text { Institution of Learning }\end{array}$ & $\begin{array}{l}\text { Nigeria } \\
+\mathrm{SE}+\mathrm{ANX}\end{array}$ & $\begin{array}{l}\text { Quantitative: } \\
\text { Questionnaire }\end{array}$ & $\begin{array}{l}627 \\
\text { students }\end{array}$ & $\begin{array}{l}\text { ANOVA } \\
+ \text { Chi-Square } \\
+ \text { Correlation }\end{array}$ \\
\hline $\begin{array}{l}\text { Adewole-Odeshi } \\
\text { (2014) }\end{array}$ & $\begin{array}{l}\text { Attitude of Students Towards E-learning in South- } \\
\text { West Nigerian Universities: An Application of } \\
\text { Technology Acceptance Model }\end{array}$ & Nigeria & $\begin{array}{l}\text { Quantitative: } \\
\text { Questionnaire }\end{array}$ & $\begin{array}{l}387 \\
\text { Students }\end{array}$ & $\begin{array}{l}\text { Linear } \\
\text { Regression+ } \\
\text { ANOVA + } \\
\text { T-test }\end{array}$ \\
\hline $\begin{array}{l}\text { Tshabalala, Ndeya- } \\
\text { Ndereya \& van der } \\
\text { Merwe (2014) }\end{array}$ & $\begin{array}{l}\text { Implementing Blended Learning at a Developing } \\
\text { University: Obstacles in the way }\end{array}$ & $\begin{array}{l}\text { South Africa } \\
\text { TAM + IDT }\end{array}$ & $\begin{array}{l}\text { Qualitative: } \\
\text { Interview }\end{array}$ & $\begin{array}{l}25 \\
\text { Academic } \\
\text { staff }\end{array}$ & $\begin{array}{l}\text { Thematic/ } \\
\text { Narrative }\end{array}$ \\
\hline Lwoga (2014) & $\begin{array}{l}\text { Critical success factors for adoption of web-based } \\
\text { learning management systems in Tanzania }\end{array}$ & Tanzania & $\begin{array}{l}\text { Quantitative: } \\
\text { Questionnaire }\end{array}$ & $\begin{array}{l}408 \\
\text { Students }\end{array}$ & SEM \\
\hline $\begin{array}{l}\text { Mtebe \& Raisamo } \\
\text { (2014) }\end{array}$ & $\begin{array}{l}\text { A Model for Assessing Learning Management System } \\
\text { Success In } \\
\text { Higher Education In Sub-Saharan Countries }\end{array}$ & $\begin{array}{l}\text { Tanzania } \\
\text { Net Benefit }\end{array}$ & $\begin{array}{l}\text { Quantitative: } \\
\text { Questionnaire }\end{array}$ & $\begin{array}{l}200 \\
\text { students }\end{array}$ & Regression \\
\hline Mbengo (2014) & $\begin{array}{l}\text { E-learning Adoption by Lecturers in Selected } \\
\text { Zimbabwe State Universities: An Application of } \\
\text { Technology Acceptance Model }\end{array}$ & Zimbabwe & $\begin{array}{l}\text { Quantitative: } \\
\text { Questionnaire }\end{array}$ & $\begin{array}{l}278 \\
\text { Lecturers }\end{array}$ & Regression \\
\hline Tagoe (2012) & $\begin{array}{l}\text { Students' perceptions on incorporating e-learning } \\
\text { into teaching and learning at the University of Ghana }\end{array}$ & Ghana & $\begin{array}{l}\text { Quantitative: } \\
\text { Questionnaire }\end{array}$ & $\begin{array}{l}534 \\
\text { students }\end{array}$ & Chi-Square \\
\hline $\begin{array}{l}\text { Mafuna \& } \\
\text { Wadesango (2012) }\end{array}$ & $\begin{array}{l}\text { Students' Acceptance and Experiences of the New } \\
\text { Learning Management System (LMS) -Wiseup }\end{array}$ & $\begin{array}{l}\text { South Africa } \\
\text { Model }\end{array}$ & $\begin{array}{l}\text { Quantitative: } \\
\text { Questionnaire }\end{array}$ & $\begin{array}{l}100 \\
\text { Students }\end{array}$ & $\begin{array}{l}\text { Descriptive } \\
\text { (Percentages) } \\
\end{array}$ \\
\hline $\begin{array}{l}\text { Venter, van } \\
\text { Rensburg \& Davis } \\
\text { (2012) }\end{array}$ & $\begin{array}{l}\text { Drivers of learning management system use in a } \\
\text { South African open and distance learning institution }\end{array}$ & $\begin{array}{l}\text { South Africa Modified } \\
\text { TAM2 }\end{array}$ & $\begin{array}{l}\text { Quantitative: } \\
\text { Questionnaire }\end{array}$ & $\begin{array}{l}213 \\
\text { Students }\end{array}$ & $\begin{array}{l}\text { Descriptive \& } \\
\text { Correlation }\end{array}$ \\
\hline $\begin{array}{l}\text { Macharia \& } \\
\text { Nyakwende (2010) }\end{array}$ & $\begin{array}{l}\text { Vice-Chancellors Influence on Academic Staff } \\
\text { Intentions to Use Learning Management Systems } \\
\text { (LMS) For Teaching and Learning }\end{array}$ & $\begin{array}{l}\text { Kenya TAM } \\
\text { +Organizational IT } \\
\text { Support+ VC } \\
\text { Characteristics+ Top } \\
\text { Management Support+ } \\
\text { Organizational Readiness } \\
\text { + Availability of ICTS }\end{array}$ & $\begin{array}{l}\text { Quantitative: } \\
\text { Questionnaire }\end{array}$ & $\begin{array}{l}82 \\
\text { Lecturers }\end{array}$ & $\begin{array}{l}\text { Correlation } \\
\text { \& Regression }\end{array}$ \\
\hline Erah \& Dairo (2008) & $\begin{array}{l}\text { Pharmacy Students Perception of the Application of } \\
\text { Learning Management System in Patient-oriented } \\
\text { Pharmacy Education: University of Benin Experience }\end{array}$ & $\begin{array}{l}\text { Nigeria } \\
\text { Model }\end{array}$ & $\begin{array}{l}\text { Quantitative: } \\
\text { Questionnaire }\end{array}$ & $\begin{array}{l}165 \\
\text { Students }\end{array}$ & $\begin{array}{l}\text { Descriptive } \\
\text { (Percentages) }\end{array}$ \\
\hline
\end{tabular}


APPENDIX B

Structure of Review Process

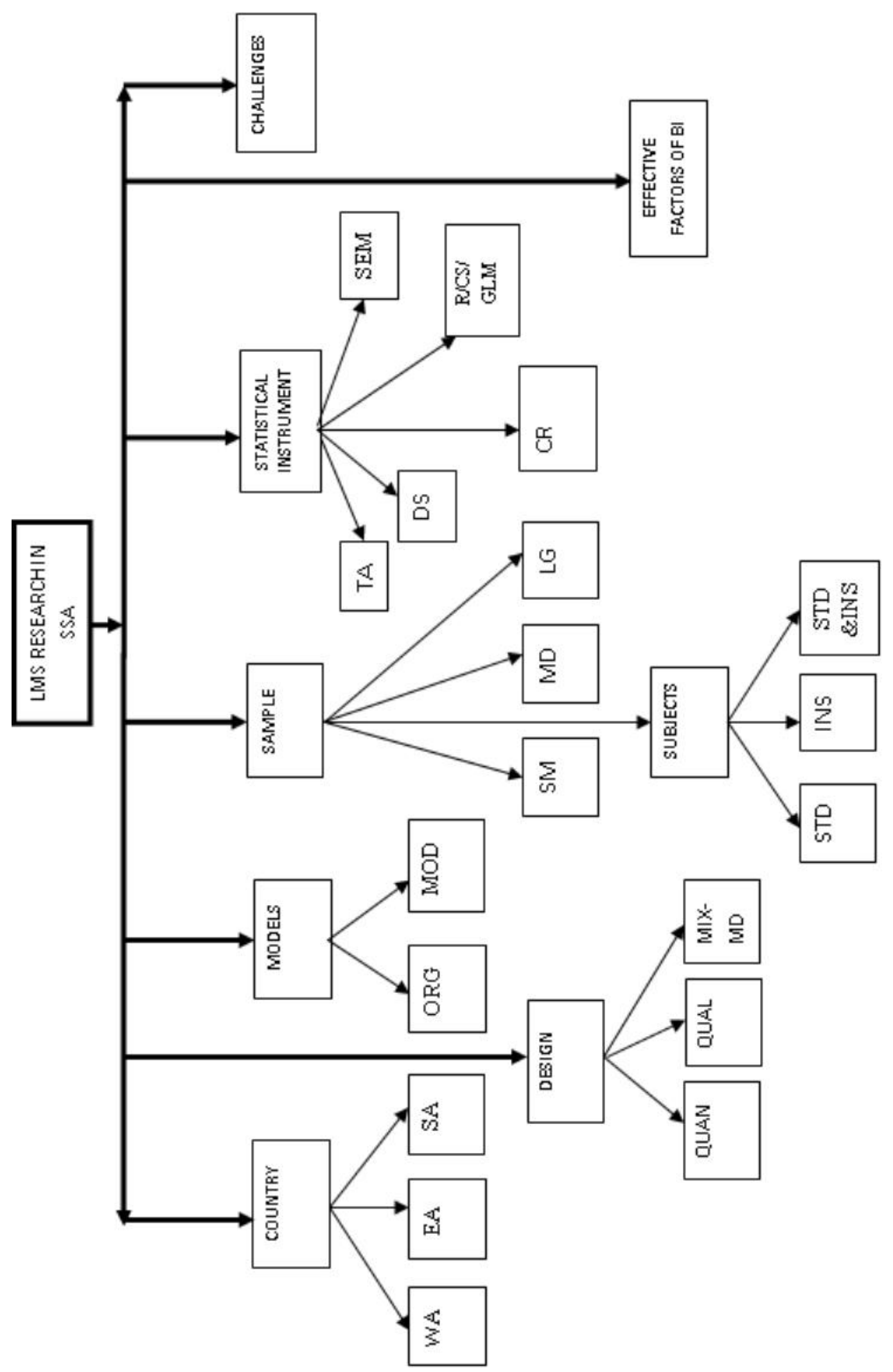




\section{Key}

WA=Western Africa

EA= Eastern

$\mathbf{S A}=$ Southern Africa

QUAN=Quantitative

QUAL=Qualitative

MX-MD=Mixed Method

ORG=Original Model

MOD= Modified Model

SM=Small

MD=Medium

LG=Large

STD=Students

INS=Instructors

STD\&INS=Students \& Instructors

TA=Thematic Analysis

DS=Descriptive Statistics

$\mathrm{CR}=$ Correlation

R/CS/GLM= Regression/Chi-Square/General Linear Models

SEM=Structural Equation Modelling

\section{http://www.ejmste.com}

